\title{
SAR distribution of non-invasive hyperthermia with microstrip applicators on different breast cancer stages
}

\author{
Wong Vei Ling ${ }^{1}$, Kasumawati Lias ${ }^{2}$, Norlida Buniyamin ${ }^{3}$, Hazrul Mohamed Basri ${ }^{4}$, Mohammad \\ Zulkaranen Ahmad Narihan ${ }^{5}$ \\ 1,2,4Faculty of Engineering, Universiti Malaysia Sarawak, Malaysia \\ ${ }^{3}$ Faculty of Electrical Engineering, Universiti Teknologi MARA (UiTM), Malaysia \\ ${ }^{5}$ Faculty of Medical and Health Sciences, Universiti Malaysia Sarawak, Malaysia
}

\begin{tabular}{|c|c|}
\hline Article Info & ABSTRACT \\
\hline Article history: & This paper presents the microstrip antenna with different applied frequencies \\
\hline Received Oct 30, 2020 & used as a non-invasive hyperthermia applicator. This non-invasive \\
\hline Revised Jan 17, 2021 & $\begin{array}{l}\text { nypertnermia applicator is introauce to clarily the sumicient neat } \\
\text { distribution on the treated tissue for different breast cancer stages. } 57\end{array}$ \\
\hline Accepted Mar 3, 2021 & mammogram breast cancer images from early-stage to stage- 3 are analyzed \\
\hline Keywords: & $\begin{array}{l}\text { the simulation-based experiment is carried out to observe the heating } \\
\text { distribution on different stages of cancer with two different operating }\end{array}$ \\
\hline Electromagnetics & frequencies; $915 \mathrm{MHz}$ and $2450 \mathrm{MHz}$. Also included in this paper is the \\
\hline Hyperthermia & Based on the results, various penetration depths are obtained when different \\
\hline Microstrip antenna & operating frequencies are applied. $915 \mathrm{MHz}$ antenna showed better results \\
\hline Penetration depth & when compared to $2450 \mathrm{MHz}$, where microstrip applicator with $915 \mathrm{MHz}$ is \\
\hline Specific absorption rate & $\begin{array}{l}\text { able to heat cancer at stage- } 1 \text {, stage- } 2 \text {, and stage- } 3 \text { with good penetration } \\
\text { depth and focus position distance, while } 2450 \mathrm{MHz} \text { only performed well in } \\
\text { early-stage cancer. Meanwhile, different stages require various periods of } \\
\text { time. From the results, the shortest period for hyperthermia execution } \\
\text { simulated in the early-stage and then followed by stage- } 3 \text {, stage- } 2 \text {, and the } \\
\text { longest period is in stage-1. }\end{array}$ \\
\hline
\end{tabular}

This is an open access article under the CC BY-SA license.

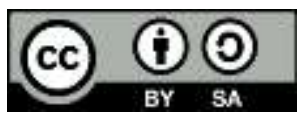

\section{Corresponding Author:}

Wong Vei Ling

Faculty of Engineering

Universiti Malaysia Sarawak (UNIMAS)

94300, Kota Samarian, Sarawak, Malaysia

Email: veilingwong@gmail.com

\section{INTRODUCTION}

Hyperthermia is a cancer treatment procedure by inducing heat to form a biological effect on the treated tissue [1]. Hyperthermia uses high temperature with a range of $41^{\circ} \mathrm{C}$ to $45^{\circ} \mathrm{C}$ at certain periods in order to denature cancerous tissue into necrotic tissue. This hyperthermia treatment procedure (HTP) is often used with chemotherapy and radiotherapy, which is known as adjuvant therapy $[2,3]$. In recent years, the successful number of hyperthermia treatments as the adjuvant procedure has been increased [4]. It showed that hyperthermia treatment has a high potential to be used as an alternative treatment for cancer. Currently, various researches of non-invasive HTP applications were presented. Based on previous research, this hyperthermia technique was able to destroy the cancerous tissue with minimal side effects [2, 5, 6]. This is because the non-invasive method is safer as no minor surgery is involved to avoid bleeding, and other adheres effects $[4,7,8]$. However, several limitations such as poor penetration depth, difficulty to control 
focus position distance, and massive skin burn problems need to be improved, especially when non-invasive hyperthermia is concerned [9, 10]. Therefore, various researches such as [2, 3, 11-13] are carried out to improve the HTP performance.

Hyperthermia treatment can be applied either with ultrasound or electromagnetic (EM) techniques. If compared to both methods, the electromagnetic technique is safer than ultrasound [14]. Hence, a microstrip antenna is used and modeled with SEMCAD X 14.8.4 to further investigate its effect on hyperthermia treatment of different breast cancer stages in this research.

In addition, most previous HTP researches such as $[2,5,11,15-21]$ are only using specific size and location of cancer data, while practically, size and location of cancer incidences will be different [22, 23]. A specific concern whereby an improvement and enhancement of HTP applicator that able to cater to different sizes and locations are significantly required to be further investigated. Therefore, this research aims to investigate the most efficient applied frequency and estimate the treatment period for different breast cancer stages. SEMCAD X 14.8.4 software simulator is used to conduct the simulation-based experiment to attain the SAR distribution, representing the focus position distance on treated tissue.

\section{RESEARCH METHODOLOGY}

A research methodology is discussed in three Sections: 2.1 microstrip antenna development, 2.2 average breast cancer size analysis, and 2.3 treatment period estimation. The design of simulations is presented in Figure 1. Details on the research methodologies are discussed in Section 2.1 to 2.3 and followed by results and discussion in Section 3.

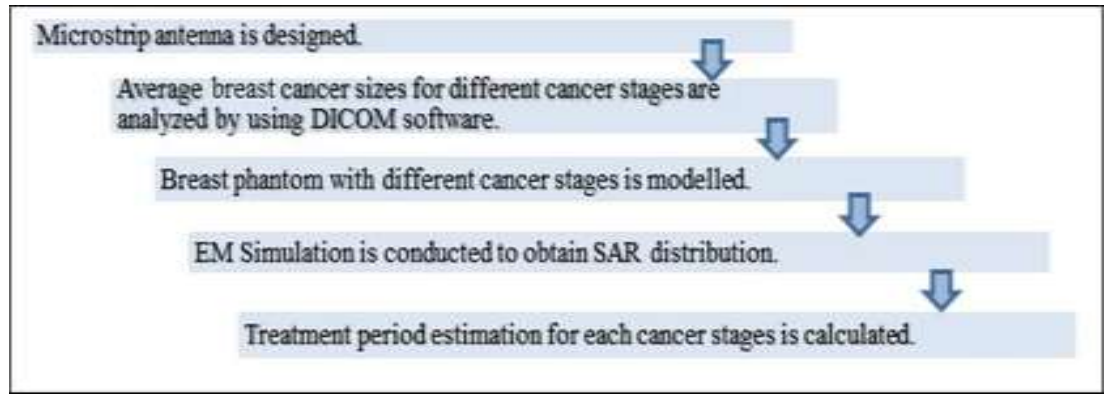

Figure 1. Flow chart for design of simulations

\subsection{Microstrip antenna development}

Microstrip antenna is selected to be used as its thickness and size can be manipulated through various frequencies, miniaturization factor, and array types enhancement [14]. Microstrip antenna can be designed and developed with various shapes. However, in this research, rectangular shape is emphasized as it has the widest beamwidth if compared to other shapes. Furthermore, this rectangular shape is easier to be modified when different operating frequencies are utilized [24]. In addition, the size of the microstrip patch is associated significantly with the operating frequency $[25,26]$. This can also be observed from (1) to (7) for rectangular microstrip development [24].

As mentioned in [24], rectangular microstrip antenna width, $W$ is obtained through (1), where $C_{o}, f_{o}$, and $\varepsilon_{r}$ represent the speed of light, fundamental frequency applied, and permittivity of the substrate, respectively. The substrate chosen in this research is RO 4350 with permittivity value, $\varepsilon_{r}=3.48$, referred to Gabriel Database built-in SEMCAD X.

$$
W=\frac{C o}{2 f_{o} \sqrt{\left(\varepsilon_{r}+1\right) / 2}}
$$

The effective permittivity can be calculated with value of width, $W$ and the thickness of the substrate used, $h$ as in (2).

$$
\varepsilon_{e f f}=\frac{\varepsilon_{r}+1}{2}+\frac{\varepsilon_{r}-1}{2}\left[\frac{1}{\sqrt{\left(1+\frac{12 h}{W}\right.}}\right]
$$


The microstrip antenna effective length, $L_{e f f}$ is calculated as in (3). It needed to determine the actual length of the antenna, $L$ as shown in (5) with identified fringing effect, $\Delta$, . Because of the EM wave are radiated outside of the strip, $L$ and $\varepsilon_{r}$ are different with $L_{e f f}$ and $\varepsilon_{e f f}$.

$$
\begin{aligned}
& L_{e f f}=\frac{C o}{2 f_{o} \sqrt{\varepsilon_{e f f}}} \\
& \Delta L=0.412 \frac{\left(\varepsilon_{e f f}+0.3\right)\left(\frac{w}{h}+0.268\right)}{\left(\varepsilon_{e f f}-0.258\right)\left(\frac{w}{h}+0.8\right)} \\
& L=L_{e f f}-2 \Delta L
\end{aligned}
$$
respectively.

The ground plate length, $\mathrm{L}_{\mathrm{g}}$ and width, $\mathrm{W}_{\mathrm{g}}$ of the rectangular antenna are obtained as in (6) and (7),

$$
\begin{aligned}
& L g=6 h+L \\
& W g=6 h+W
\end{aligned}
$$

Table 1 presents the rectangular microstrip antenna sizes with operating frequencies of $915 \mathrm{MHz}$ and 2450MHz. Meanwhile, in Figure 2 (a) and (b), it shows modeling of the antenna with breast phantom under $915 \mathrm{MHz}$ and $2450 \mathrm{MHz}$, respectively.

Table 1. Designs of rectangular microstrip antenna under frequency $915 \mathrm{MHz}$ and $2450 \mathrm{MHz}$

\begin{tabular}{ccccccccc}
\hline Frequency, $\mathrm{MHz}$ & $\mathrm{h}, \mathrm{mm}$ & $\mathrm{W}, \mathrm{mm}$ & $\varepsilon_{\text {eff }}, \mathrm{mm}$ & $L_{\text {eff }}, \mathrm{mm}$ & $\Delta L, \mathrm{~mm}$ & $\mathrm{~L}, \mathrm{~mm}$ & $\mathrm{~L}_{\mathrm{g}}, \mathrm{mm}$ & $\mathrm{W}_{\mathrm{g}, ~} \mathrm{~mm}$ \\
\hline 915 & 1 & 109.46 & 3.42 & 88.62 & 0.48 & 87.66 & 93.66 & 115.46 \\
2450 & 1 & 40.88 & 3.33 & 33.53 & 0.48 & 32.57 & 38.57 & 46.88 \\
\hline
\end{tabular}

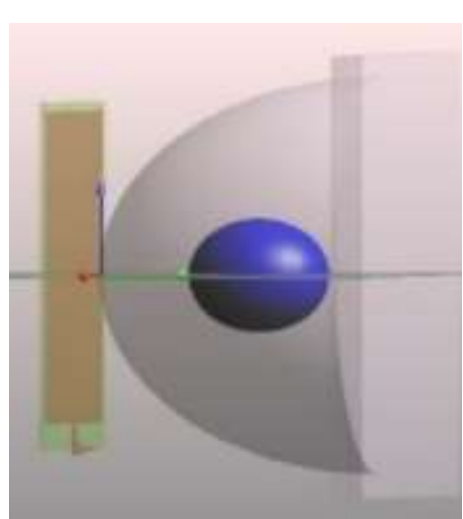

(a)

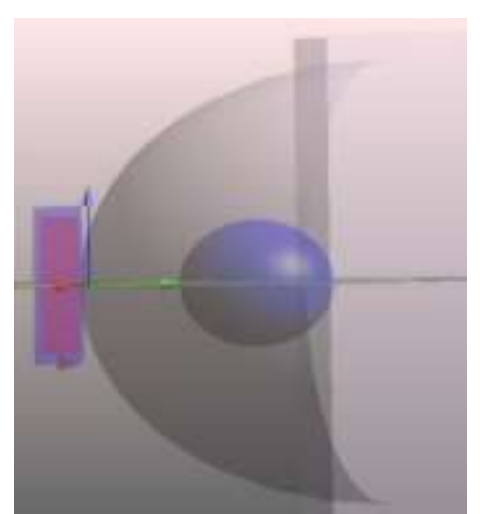

(b)

Figure 2. Modelling of microstrip antenna with breast phantom under (a) $915 \mathrm{MHz}$ and (b) $2450 \mathrm{MHz}$

\subsection{Average breast cancer size analysis}

Mammogram is an imaging methods for screening breast cancer [27]. 57 mammogram breast cancer images are gathered from one of the General Hospital in Malaysia. As the details of hospital and raw data are confidential under ethical approval, only the analyzed results are presented in this section. The images included breast cancer from early-stage until stage-3. Stage-4 breast cancer mammogram images are not discussed because it will be directly referred for surgical procedure.

Data analysis is proceed with digital imaging and communications in medicine (DICOM) software. The depth and size of the cancer tissue are determined and analyzed with the mentioned software. The surface depth and inner depth of breast cancer in each stage are measured as showed in Figure 3 . While the average surface depth and inner are calculated according to the number of samples obtained. 
Figure 4 shows the average surface depth and inner depth for each cancer stage that attain from the quantitative images analysis approach. The depths are basically to identify the required focus position distance and penetration depth of each cancer that necessitates being heated for hyperthermia execution. Breast phantoms consisting of breast fat with 4 inches $(10.16 \mathrm{~cm})$ and breast cancer with the analyzed size from mammograms images analysis for each stage are modeled as Figure 2. The data showed in Figure 4 are agreed with the result by Wang et al. [28] in 2014 with the almost similar cancer depth and sizes.

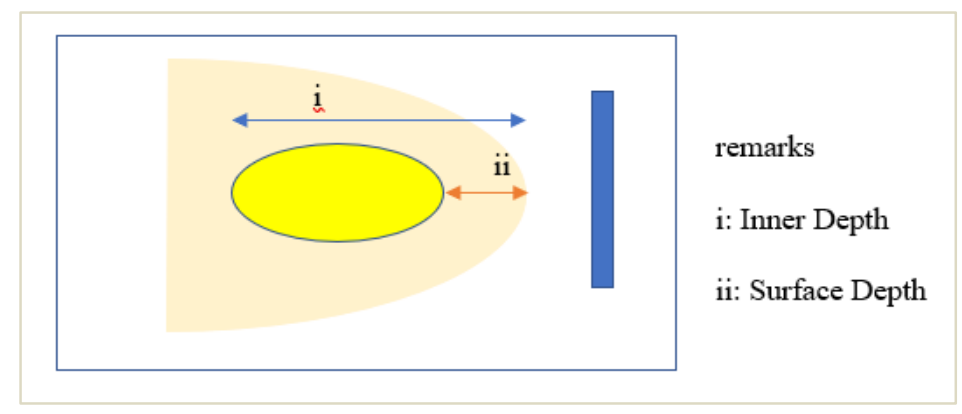

Figure 3. Surface depth and inner depth measurements

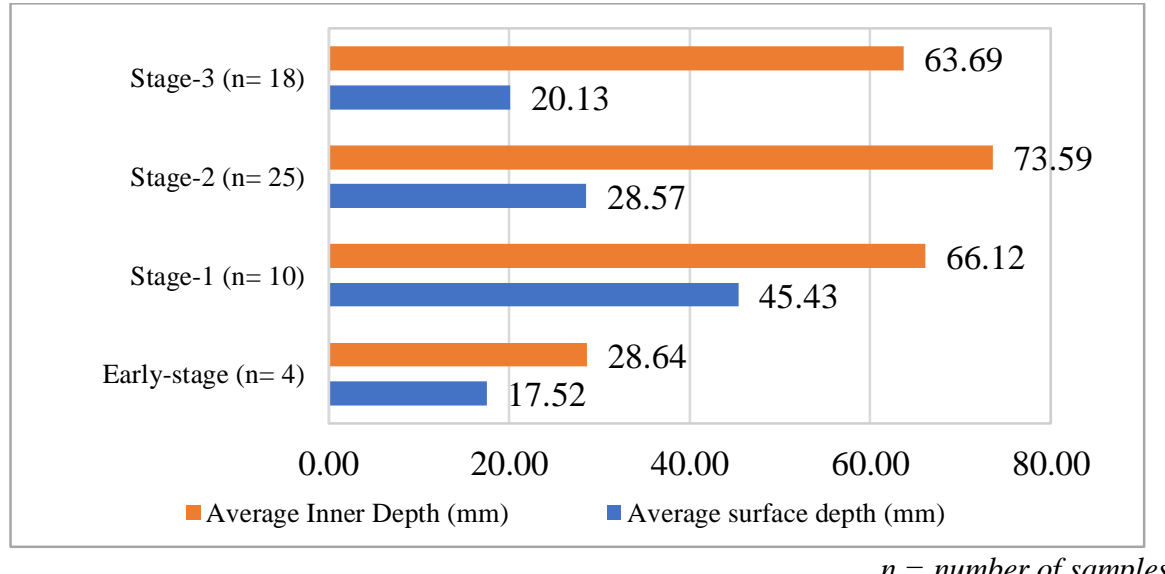

Figure 4. Surface and inner depth for each cancer stage

\subsection{Treatment period estimation}

In order to estimate for the hyperthermia treatment period, a specific absorption rate (SAR) equation is referred. SAR is a measurement of energy absorption rate per unit mass of biological tissues during radiofrequency (RF) or microwave (MW) types of EM waves radiation. Generally, SAR parameters are presented in units of watts per kilogram or milli-watts per gram (W/kg or $\mathrm{mW} / \mathrm{g})[15,29]$.

Referring to the international electrotechnical commission (IEC) and Institute of Electrical and Electronics Engineers (IEEE), IEC/IEEE 62704-1 standard, SAR can be determined as in (8) and when the electric field is considered, (9) is used [30].

$$
\begin{aligned}
& S A R=\frac{\delta}{\delta t}\left(\frac{\delta W}{\rho \delta V}\right) \\
& S A R=\frac{\sigma E^{2}}{2 \rho}
\end{aligned}
$$

Moreover, the SAR also can be written as (10), when temperature and period are considered.

$$
S A R=\left.\frac{c \Delta T}{\Delta t}\right|_{t=0}
$$


$W, t, V, E, \rho, T, \sigma$ and $c$ are represented energy absorbed (Watt), time duration (second), tissue volume $\left(\mathrm{m}^{3}\right)$, peak electric field vector $(\mathrm{V} / \mathrm{m})$, tissue density $\left(\mathrm{kg} / \mathrm{m}^{3}\right)$, tissue temperature $\left({ }^{\circ} \mathrm{C}\right)$, tissue conductivity $(\mathrm{S} / \mathrm{m})$ and tissue specific heat capacity $\left(\mathrm{J} / \mathrm{kg}^{\circ} \mathrm{C}\right)$, respectively. Therefore, after SAR distribution obtained from EM-simulation is recorded, the time taken for the hyperthermia treatment can be calculated as (10). The specific heat capacity of breast cancer tissue and required increasing temperature until 41 to $45^{\circ} \mathrm{C}$ are $3510 \mathrm{~J} / \mathrm{kg}^{\circ} \mathrm{C}$ and 4 to $8^{\circ} \mathrm{C}$, respectively [16].

\section{RESULTS AND DISCUSSION}

The microstrip antenna with 915 and $2450 \mathrm{MHz}$ and breast phantom of different breast cancer stages are modeled with SEMCAD X 14.8.4. In order to obtain SAR distribution, EM-simulation is carried out. A few parameters are required to be set in the SEMCAD $\mathrm{X}$ before the simulation is run. Table 2 shows permittivity $(\varepsilon)$, electrical conductivity $(\mathrm{EC}, \mathrm{S} / \mathrm{m})$ and specific heat capacity $\left(\mathrm{c}, \mathrm{J} / \mathrm{kg}^{\circ} \mathrm{C}\right.$ ) of $915 \mathrm{MHz}$ and $2450 \mathrm{MHz}$ that are obtained from Gabriel Database build-in SEMCAD X, finding by Hussien et al. [9] and typical heat properties, which is used in the bio-heat transfer from [16].

Table 2. Electrical and thermal properties of elements used

\begin{tabular}{|c|c|c|}
\hline Elements & $915 \mathrm{MHz}$ & $2450 \mathrm{MHz}$ \\
\hline \multicolumn{3}{|l|}{ Substrate (RO4350) } \\
\hline Permittivity, $\varepsilon$ & 3.48 & 3.48 \\
\hline Electrical conductivity, S/m & 0.00077 & 0.00077 \\
\hline Specific heat capacity, $\mathrm{J} / \mathrm{kg}^{\circ} \mathrm{C}$ & $1 \times 10^{-12}$ & $1 \times 10^{-12}$ \\
\hline \multicolumn{3}{|l|}{ Patch (Copper) } \\
\hline Permittivity, $\varepsilon$ & 1 & 1 \\
\hline Electrical conductivity, S/m & $5.813 \times 10^{7}$ & $5.813 \times 10^{7}$ \\
\hline Specific heat capacity, $\mathrm{J} / \mathrm{kg}^{\circ} \mathrm{C}$ & $1 \times 10^{-12}$ & $1 \times 10^{-12}$ \\
\hline \multicolumn{3}{|l|}{ Breast Tissue } \\
\hline Permittivity, $\varepsilon$ & 3.11433 & 3.24886 \\
\hline Electrical conductivity, S/m & 0.88985 & 0.80329 \\
\hline Specific heat capacity, $\mathrm{J} / \mathrm{kg}^{\circ} \mathrm{C}$ & 3550 & 3550 \\
\hline \multicolumn{3}{|l|}{ Cancer Tissue } \\
\hline Permittivity, $\varepsilon$ & 74.45 & 72.81 \\
\hline Electrical conductivity, S/m & 1.88 & 2.72 \\
\hline Specific heat capacity, $\mathrm{J} / \mathrm{kg}^{\circ} \mathrm{C}$ & 3510 & 3510 \\
\hline
\end{tabular}

The operating power and mass of SAR average over cube controlled at $1 \mathrm{~W}$ and $1 \mathrm{~g}$ during the simulation. The distance between antenna and breast phantom is fixed with $0 \mathrm{~mm}$, which means it is directly in contact with the skin. Figures 5-8 show SAR distribution results with different applied frequencies in each cancer stage, and Table 3 presents the focus position and SAR, respectively.

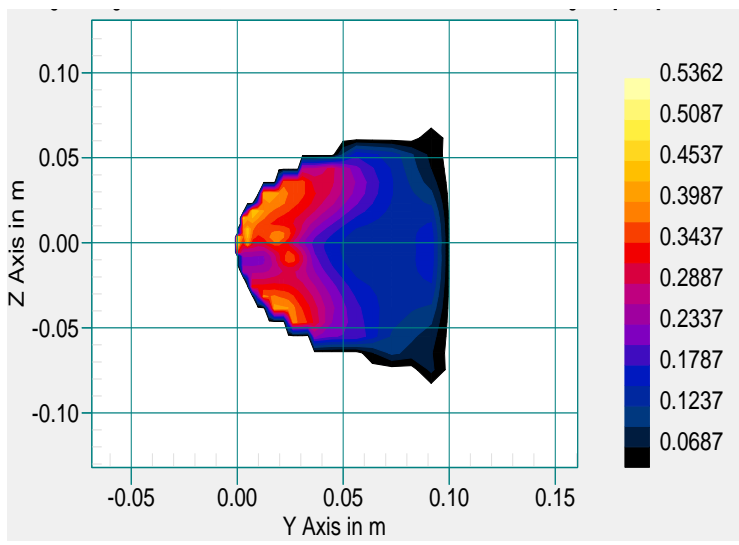

(a)

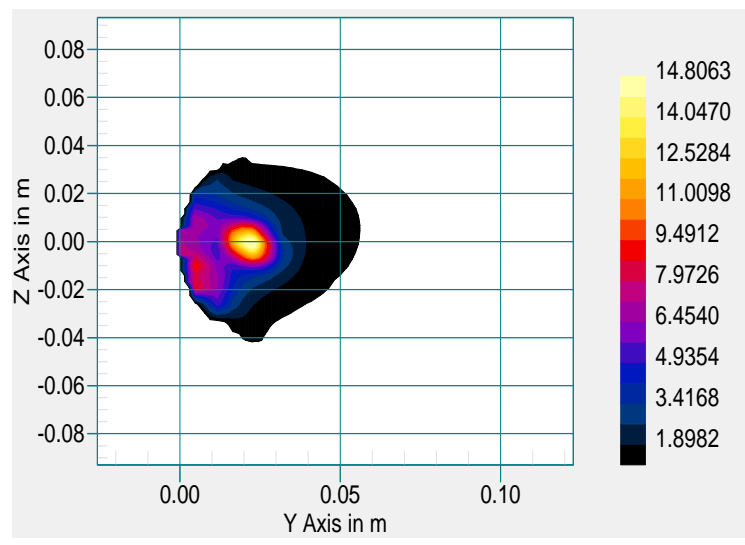

(b)

Figure 5. Early stage cancer SAR distribution results in (a) $915 \mathrm{MHz}$ and (b) $2450 \mathrm{MHz}$ 


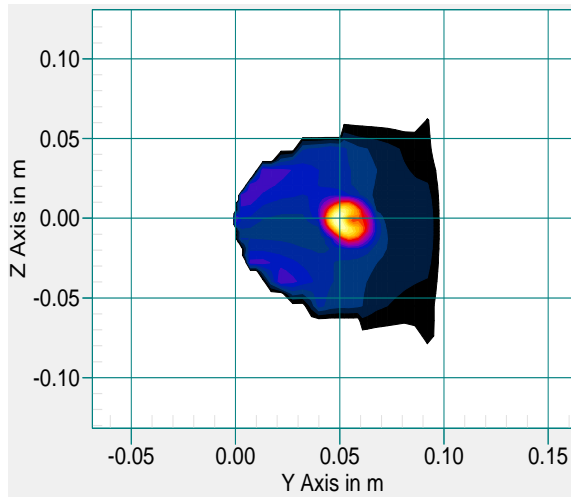

(a)

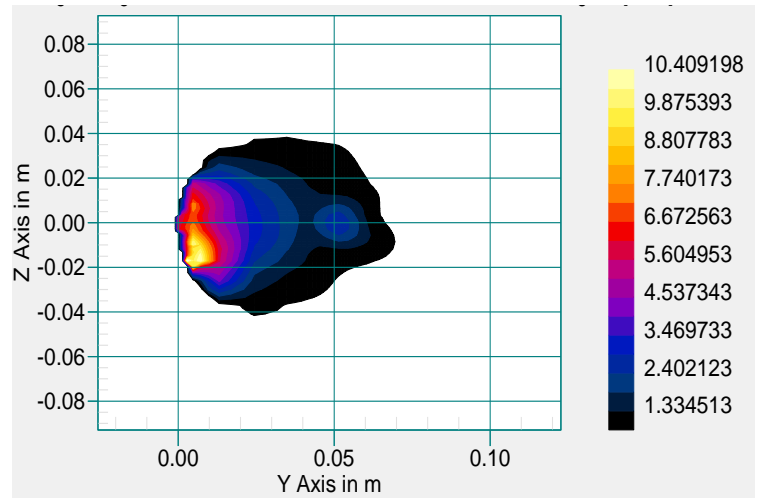

(b)

Figure 6. Stage 1 cancer SAR distribution results in (a) $915 \mathrm{MHz}$ and (b) $2450 \mathrm{MHz}$

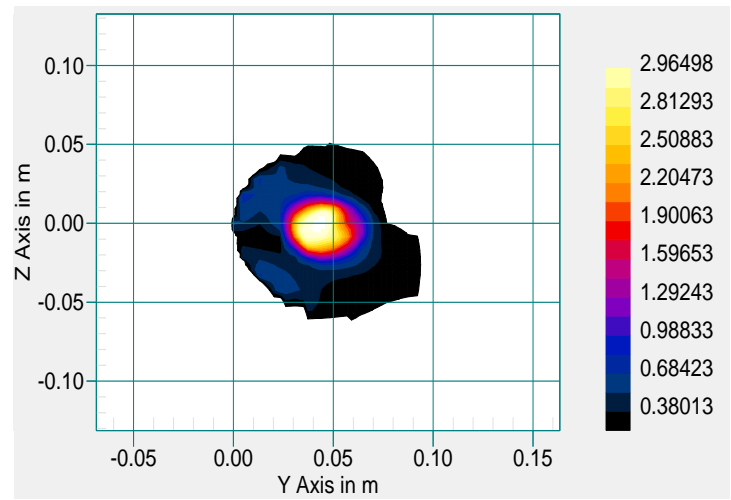

(a)

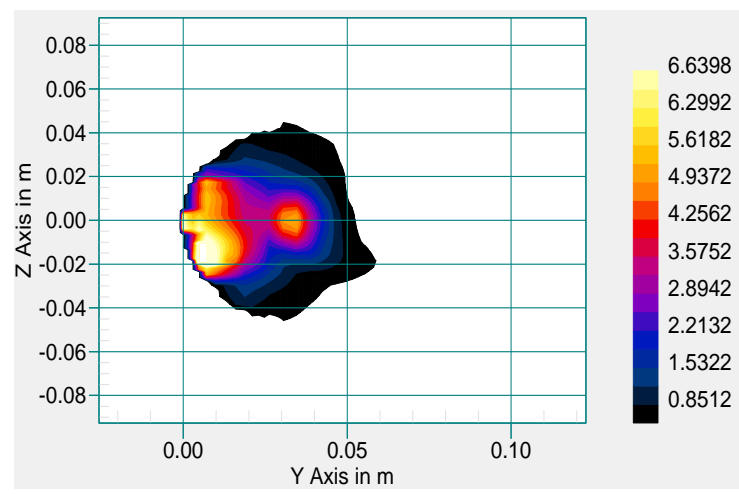

(b)

Figure 7. Stage 2 cancer SAR distribution results in (a) $915 \mathrm{MHz}$ and (b) $2450 \mathrm{MHz}$

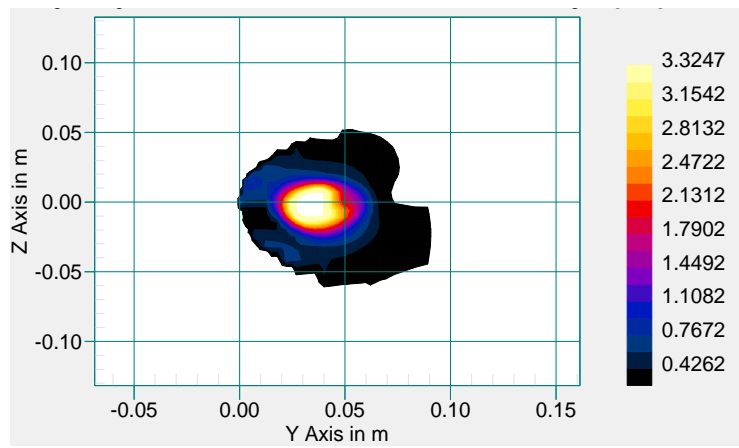

(a)

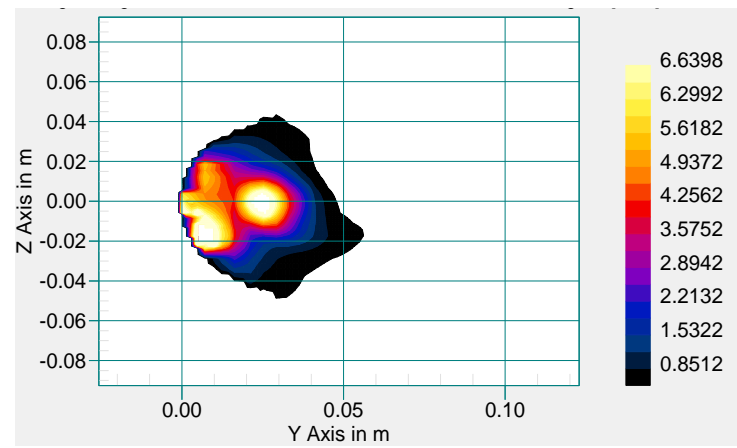

(b)

Figure 8. Stage 3 cancer SAR distribution results in (a) $915 \mathrm{MHz}$ and (b) $2450 \mathrm{MHz}$

Table 3. Focus position distance (FPD) and peak-spatial-average SAR results with 915 and $2450 \mathrm{MHz}$ microstrip antenna

\begin{tabular}{|c|c|c|c|c|c|c|c|c|}
\hline \multirow[b]{2}{*}{ Frequency } & \multicolumn{2}{|c|}{ Early Stage } & \multicolumn{2}{|c|}{ Stage 1} & \multicolumn{2}{|c|}{ Stage 2} & \multicolumn{2}{|c|}{ Stage 3} \\
\hline & $\begin{array}{l}\text { FPD } \\
(\mathrm{mm})\end{array}$ & $\begin{array}{c}\text { SAR } \\
(\mathrm{mW} / \mathrm{g})\end{array}$ & FPD (mm) & $\begin{array}{c}\text { SAR } \\
(\mathrm{mW} / \mathrm{g})\end{array}$ & $\begin{array}{l}\text { FPD } \\
(\mathrm{mm})\end{array}$ & $\begin{array}{c}\text { SAR } \\
(\mathrm{mW} / \mathrm{g})\end{array}$ & $\begin{array}{l}\text { FPD } \\
(\mathrm{mm})\end{array}$ & $\begin{array}{c}\text { SAR } \\
(\mathrm{mW} / \mathrm{g})\end{array}$ \\
\hline $915 \mathrm{MHz}$ & $0-24$ & 0.60 & $43-63$ & 1.21 & $29-61$ & 3.01 & $20-51$ & 3.38 \\
\hline $2450 \mathrm{MHz}$ & $15-27$ & 15.2 & $\begin{array}{l}\text { EM-wave not } \\
\text { covered into } \\
\text { cancer region }\end{array}$ & N/A & $\begin{array}{c}0-16 \& \\
27-36\end{array}$ & 6.81 & $0-34$ & 6.81 \\
\hline
\end{tabular}


As shown in Figures 5-8, and Table 3, $2450 \mathrm{MHz}$ is the most suitable for early-stage cancer, where the heat from the microstrip antenna has heated cancer with good focus position distance and penetration depth. Furthermore, the location of cancer for the early-stage is near to the skin. According to the Universal Wave Equation, $=\frac{f}{\lambda}$, and wavelength is directly proportional to the penetration depth of the wave. Thus, a $2450 \mathrm{MHz}$ antenna with higher gain but low penetration depth is suitable for early-stage cancer. Meanwhile, a $915 \mathrm{MHz}$ antenna with higher wavelength and penetration depth is performed better than the $2450 \mathrm{MHz}$ antenna for Stage-1, -2, and -3 breast cancer, where cancer locations are located in the deeper region. These research results can be validated with findings by [31], whereas temperature or SAR distribution with $2450 \mathrm{MHz}$ antenna decreased rapidly when propagation distance increased.

Furthermore, with the resulted Peak-Spatial-Average SAR, the estimation of treatment periods can be calculated through (10) with specific capacity of breast cancer tissue $3510 \mathrm{~J} / \mathrm{kg}^{\circ} \mathrm{C}$ and required temperature increment from 4 to $8{ }^{\circ} \mathrm{C}$ as follows:

a) Early Stage:

$$
\begin{aligned}
& d t_{1}=\frac{3510(4)}{15.2}=923.68 \text { seconds } \\
& d t_{2}=\frac{3510(8)}{15.2}=1847.37 \text { seconds }
\end{aligned}
$$

Thus, the early cancer stage required 15.39 minutes until 30.78 minutes for the treatment with a $2450 \mathrm{MHz}$ antenna. With similar calculation steps, the treatment period estimation for Stage-1, -2 and -3 are: b) Stage-1: 193.39 minutes until 386.77 minutes with $915 \mathrm{MHz}$ antenna.

c) Stage-2: 77.74 minutes until 155.48 minutes with $915 \mathrm{MHz}$ antenna.

d) Stage-3: 69.23 minutes until 138.46 minutes with $915 \mathrm{MHz}$ antenna.

The treatment period estimation is important in further research as it can validate the efficiency of prototype fabricated. The animal studies mentioned in [32] also stated that 60 to 360 minutes are required to reach $42^{\circ} \mathrm{C}$ by using HTP. While [31] also proved that the increase of temperature and treatment periods could be affected by applied frequency, electrical properties of tissue and required penetration depth.

\section{CONCLUSION}

Hyperthermia SAR simulation in different frequencies is essential for future research as the most suitable frequency can be identified when targeted to various sizes, stages, or locations of breast cancer. Thus, microstrip antenna with $915 \mathrm{MHz}$ and $2450 \mathrm{MHz}$ are modeled with SEMCAD X software simulator to obtain the SAR distribution on different breast cancer stages. Based on the results, it is observed that $915 \mathrm{MHz}$ is good to be applied for breast cancer stage- 1 to stage- 3 , while $2450 \mathrm{MHz}$ is performed well for early-stage cancer. In addition, different stages of cancers have different estimation of the hyperthermia execution treatment period. This period is significant to ensure hyperthermia is executed well with the required temperature range. Overall, from the results, $915 \mathrm{MHz}$ operating frequency is the most suitable frequency that able to perform better for most of the cancer stages. Beside clarifying the most suitable applied frequency for different breast cancer stages, in our further research, the SAR distribution or SAR coverage will be further improved by integrating various antenna designs, enhancing the lens structure as well as metamaterial structures in order to enhance the performance of HTP with less unwanted hot spots area and minimize the adverse health effects, simultaneously.

\section{ACKNOWLEDGEMENTS} support.

The authors would like to thank the Faculty of Engineering, Universiti Malaysia Sarawak for the

\section{REFERENCES}

[1] Y. Yagawa, K. Tanigawa, Y. Kobayashi, and M. Yamamoto, "Cancer immunity and therapy using hyperthermia with immunotherapy, radiotherapy, chemotherapy, and surgery," J. Cancer Metastasis Treat., vol. 3, no. 10, p. 218, Oct. 2017.

[2] K. Lias, M. Z. A. Narihan, and N. Buniyamin, "An antenna with an embedded ebg structure for non invasive hyperthermia cancer treatment," in IECBES 2014, Conference Proceedings-2014 IEEE Conference on Biomedical Engineering and Sciences: "Miri, Where Engineering in Medicine and Biology and Humanity Meet," 2014, no. December 2014, pp. 618-621, doi: 10.1109/IECBES.2014.7047577 
[3] Y. S. Koo, R. Kazemi, Q. Liu, J. C. Phillips, and A. E. Fathy, "Development of a high SAR conformal antenna for hyperthermia tumors treatment," IEEE Trans. Antennas Propag., vol. 62, no. 11, pp. 5830-5840, 2014, doi: 10.1109/TAP.2014.2357419.

[4] S. Jha, P. K. Sharma, and R. Malviya, "Hyperthermia: role and risk ractor for cancer treatment," Achiev. Life Sci., vol. 10, no. 2, pp. 161-167, 2016, doi: 10.1016/j.als.2016.11.004.

[5] E. Korkmaz, O. Isik, and S. Kara, "Electromagnetic modeling of a female breast hyperthermia applicator," in IEEE Antennas and Propagation Society, AP-S International Symposium (Digest), 2013, pp. 2048-2049, doi: 10.1109/APS.2013.6711682.

[6] N. Sharma, B. Jain, P. Singla, and R. R. Prasad, "Rectangular patch microstrip antenna: a survey," Int. Adv. Res. J. Sci. Eng. Technol., vol. 1, no. 3, pp. 144-147, 2014.

[7] P. Chalasani, A. Agarwal, and A. Patel, "Targeted therapies in hematological malignancies," in Current Cancer Treatment - Novel Beyond Conventional Approaches, InTech, 2011, pp. 455-474, doi: 10.5772/22170.

[8] K. P. Tamarov et al., "Radio frequency radiation-induced hyperthermia using Si nanoparticle-based sensitizers for mild cancer therapy," Sci. Rep., vol. 4, 2014, doi: 10.1038/srep07034.

[9] M. Hussein, F. Awwad, D. Jithin, H. El Hasasna, K. Athamneh, and R. Iratni, "Breast cancer cells exhibits specific dielectric signature in vitro using the open-ended coaxial probe technique from $200 \mathrm{MHz}$ to $13.6 \mathrm{GHz}$," Sci. Rep., vol. 9, no. 1, pp. 1-8, 2019, doi: 10.1038/s41598-019-41124-1.

[10] S. Park, J. Hwang, Y. Kwon, and C. Cheon, "A new antenna system for microwave non-invasive hyperthermia lipolysis," Proc. Annu. Int. Conf. IEEE Eng. Med. Biol. Soc. EMBS, vol. 2, pp. 5683-5686, 2012, doi: 10.1109/EMBC.2012.6347285.

[11] W. C. Choi, S. Lim, and Y. J. Yoon, "Evaluation of transmit-array lens antenna for deep-seated hyperthermia tumor treatment," IEEE Antennas Wirel. Propag. Lett., vol. 19, no. 5, pp. 1-1, 2020, doi: 10.1109/LAWP.2020.2982676.

[12] D. Vrba, D. B. Rodrigues, J. Vrba (Jr.), and P. R. Stauffer, "Metamaterial antenna arrays for improved uniformity of microwave hyperthermia treatments," Prog. Electromagn. Res., vol. 156, no. April, pp. 1-12, 2016, doi: 10.2528/PIER16012702.

[13] Y. Tao and G. Wang, "Influence of source offset on breast tumor hyperthermia with $\Gamma$-shaped LHM lens applicator," in 2010 Int. Conf. Microw. Millim. Wave Technol. ICMMT 2010, pp. 1859-1861, 2010, doi: 10.1109/ICMMT.2010.5524876.

[14] K. Lias, N. Buniyamin, and M. Z. B. A. Narihan, "An overview of cancer thermal therapy technology based on different types of antenna exposure," in 2013 International Conference on Electrical, Electronics and System Engineering, ICEESE 2013, 2013, pp. 96-101, doi: 10.1109/ICEESE.2013.6895050.

[15] K. Lias, N. Buniyamin, and M. Z. A. Narihan, "Simulation study of an EBG-M applicator towards non-invasive breast hyperthermia cancer procedure," J. Teknol., vol. 78, no. 5-6, pp. 75-81, 2016, doi: 10.11113/jt.v78.8641.

[16] L. Leggio, O. De Varona, and E. Dadrasnia, "A comparison between different schemes of microwave cancer hyperthermia treatment by means of left-handed metamaterial lenses," Prog. Electromagn. Res., vol. 150, no. October 2014, pp. 73-87, 2015, doi: 10.2528/PIER14101408.

[17] N. A. Jaffar, K. Lias, N. K. Madzhi, and N. Buniyamin, "Improving the performance of applicators for use in hyperthermia cancer treatment procedure by the introduction of LHM lens," Int. J. Electr. Electron. Syst. Res., vol. 14, no. 6, 2019.

[18] S. Curto and P. Prakash, "Design of a compact antenna with flared groundplane for a wearable breast hyperthermia system," Int. J. Hyperth., vol. 31, no. 7, pp. 726-736, 2015, doi: 10.3109/02656736.2015.1063170.

[19] D. A. M. Iero, L. Crocco, T. Isernia, and E. Korkmaz, "Optimal focused electromagnetic hyperthermia treatment of breast cancer," 2016 10th Eur. Conf. Antennas Propagation, EuCAP 2016, 2016, doi: 10.1109/EuCAP.2016.7481515.

[20] P. T. Nguyen, A. M. Abbosh, and S. Crozier, "3-D focused microwave hyperthermia for breast cancer treatment with experimental validation," IEEE Trans. Antennas Propag., vol. 65, no. 7, pp. 3489-3500, 2017, doi: 10.1109/TAP.2017.2700164.

[21] O. Fiser, I. Merunka, and J. Vrba, "Microwave hyperthermia system for head and neck area with noninvasive UWB temperature change detection," Prog. Electromagn. Res. Symp., vol. 3, pp. 1657-1662, 2017, doi: 10.1109/PIERS.2017.8262015.

[22] A. W. Kurian et al., "Recent trends in chemotherapy use and oncologists' Treatment Recommendations for EarlyStage Breast Cancer," JNCI J. Natl. Cancer Inst., vol. 110, pp. 493-500, 2017, doi: 10.1093/jnci/djx239.

[23] L. Xu and X. Wang, "Focused microwave breast hyperthermia monitored by thermoacoustic imaging: a computational feasibility study applying realistic breast phantoms," IEEE J. Electromagn. RF Microwaves Med. Biol., vol. 4, no. 2, pp. 81-88, 2020, doi: 10.1109/JERM.2019.2931623.

[24] S. Alam, I. Surjati, and Y. K. Ningsih, "Patch modification and slot arrangement of microstrip antenna for improving the axial ratio," in 2017 International Conference on Broadband Communication, Wireless Sensors and Powering, BCWSP 2017, 2018, vol. 2018-Janua, pp. 1-5, doi: 10.1109/BCWSP.2017.8272553.

[25] A. Banwari, N. Acharya, M. Kumar Sharma, and S. Saxena, "Low loss semicircular slotted microstrip patch antenna for ISM band application," in 2017 6th International Symposium on Next Generation Electronics, ISNE 2017, 2017, pp. 4-7, doi: 10.1109/ISNE.2017.7968718.

[26] M. Sethi and G. Nijhawan, "Design of microwave antenna for hyperthermia system," Int. J. Wirel. Microw. Technol., vol. 6, no. 4, pp. 39-47, 2016, doi: 10.5815/ijwmt.2016.04.04.

[27] M. Salimian, A. Rezai, S. Hamidpour, and F. Khajeh-khalili, "Effective features in thermal images for breast cancer detection," in 2nd National Conference on New Technologies in Electrical and Computer Engineering, 2019, pp. 1-7.

[28] Z. Wang et al., "Tumor size of breast invasive ductal cancer measured with contrast-enhanced ultrasound predicts

SAR distribution of non-invasive hyperthermia with microstrip applicators on different... (Wong Vei Ling) 
regional lymph node metastasis and N stage,” Int. J. Clin. Exp. Pathol., vol. 7, no. 10, pp. 6985-6991, 2014.

[29] G. Chakaravarthi and K. Arunachalam, "A compact microwave patch applicator for hyperthermia treatment of cancer," in 2014 36th Annual International Conference of the IEEE Engineering in Medicine and Biology Society, EMBC 2014, 2014, pp. 5320-5322, doi: 10.1109/EMBC.2014.6944827.

[30] IEC/IEEE 62704-1, 1/2017 ed. Geneva: IEC (International Electrotechnical Comission) and IEEE (Institute of Electrical and Electronics Engineers), 2017.

[31] P. Gas, "Tissue temperature distributions for different frequencies derived from interstitial microwave hyperthermia," Prz. Elektrotechniczny, vol. 88, no. 12 B, pp. 131-134, 2012.

[32] Z. Behrouzkia, Z. Joveini, B. Keshavarzi, N. Eyvazzadeh, and R. Z. Aghdam, "Hyperthermia: how can it be used?," Oman Med. J., vol. 31, no. 2, pp. 89-97, 2016, doi: 10.5001/omj.2016.19.

\section{BIOGRAPHIES OF AUTHORS}
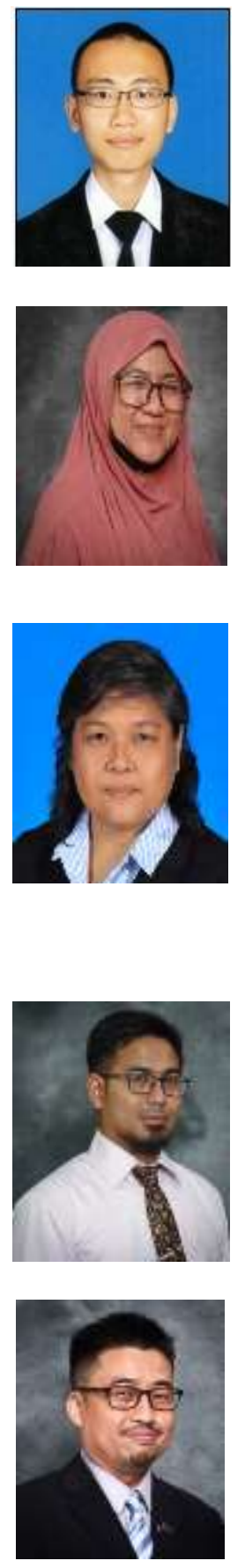

Wong Vei Ling, He completed his Bachalor of Engineering (Hons) Electrical and Electronics Engineering in year 2019 from Universiti Malaysia Sarawak (UNIMAS) and currently a Master of Engineering candidate from UNIMAS.

Dr. Kasumawati bt. Lias graduated from Universiti Malaysia Sarawak (UNIMAS) with a B.Eng (Hons) in Electronics (Telecommunication) Engineering. She obtained M.Eng in Electrical and Electronics (Telecommunication) Engineering at UTM, Johor. She received her Doctor of Philosophy in Biomedical Engineerring from Universiti Teknologi MARA (UiTM), Shah Alam, Malaysia. Currently she is a lecturer at the Department of Electrical and Electronic Engineering at the Faculty of Engineering, UNIMAS. She specializes in Hyperthermia for Cancer Treatment. She is registered with the Board of Engineers, Malaysia (BEM), and member of the Institute of Engineers Malaysia, IEM and IEEE Engineering in Medicine and Biology Society.

Professor Ir. Dr. Norlida Buniyamin graduated from the University of Adelaide, Australia with a Bachelor Degree in Electrical and Electronic Engineering (Hons.). She was a Research Fellow with the Malaysian Institute of Microelectronic Systems (MIMOS) before joining University Teknologi MARA as a lecturer in 1988. She then obtained a M.Sc. in Industrial Control System from the University of Salford, U.K in 1993 and a Ph.D. in the area of Knowledge Management for Manufacturing Enterprises in 2004 from the University of Manchester, Institute of Science and Technology (UMIST), U.K. She is now a Professor of Electrical Engineering at UiTM, a Fellow of the Institution of Engineers, Malaysia and Hon Fellow of the ASEAN Federation of Engineering Organisation (AFEO). Her current research interest is in Industrial Automation and Robotics, Biomedical Engineering, Knowledge Management and Engineering Education.

Ir. Dr. Hazrul Mohamed Basri is a senior lecturer serving the faculty of engineering, Universiti Malaysia Sarawak from 2010. He is a professional engineer in electronics discipline from the Board of Engineers Malaysia (BEM). He completed his doctoral studies in Electrical Engineering from Universiti Malaya and Master's degree from Université de Technologie de Belfort Montbéliard, France. His research interests include solar photovoltaics technology, power electronics, and renewable energy. From 2018, he became a S.E.D.A Certified GridConnected Photovoltaic Systems Designer.

Prof. Dr. Mohammad Zulkarnaen bin Ahmad Narihan is a Professor of Pathology at the Faculty of Medicine and Health Sciences, UNIMAS. A medical degree graduate from University of Cork, National University of Ireland in 1999, he went to further his specialist training in Master of Pathology in 2006. His expertise is in the field of anatomic pathology and serves as a Histopathologist in Sarawak General Hospital. 